\title{
Fiscal Implications for Rural-Urban Income Inequality: The Case of Pakistan
}

\author{
Submitted 25/03/21, $1^{\text {st }}$ revision 18/04/21, $2^{\text {nd }}$ revision 09/05/21, accepted 20/05/21

\section{Khalil Ahmad ${ }^{1}$, Safdar Ali ${ }^{2}$, Ayesha Haider ${ }^{3}$, Muhammad Shahid ${ }^{4}$, Muhammad Mudassar Naushahi ${ }^{5}$}

\begin{abstract}
:
\end{abstract}
Purpose: This study investigates the fiscal implications through taxes and total expenditures for rural-urban income inequality in Pakistan. Fiscal policy plays a significant role in stabilizing the macroeconomics variables and equal distribution of income among society. Pakistan is a good case study because there is a dual rural-urban sector that emerges with industrial development and other traditional rural agriculture-based regions.

Design/Methodology/Approach: We use time series data (1985-2018) with autoregressive distributed lag models (ARDL) for long-run and error correction models (ECM) for short span dynamic co-integration. The above models try to capture the practical effect of fiscal progress on income distribution among modern urban and traditional rural regions.

Findings: The findings show that tax side fiscal measures are more harmful to rural-urban income distribution. On the expenditure side, fiscal policy has a significant impact on all disburse income distribution. The most surprising results belong to trade liberalization, it has significantly improved income distribution in urban areas but not in the rurals. Financial development has also verified the accumulation of wealth among rural-urban areas because of the emergence of private profiteering groups in Pakistan.

Practical Implications: For policy purposes the government of Pakistan should spend on improving the quality of life of the households by investing in social goods like health, education, and foundation inequality situation may be better off. The nature of public spending and who gains the benefits from this spending decide the nature of inequality. On the supply side, the government should reduce the tax burden for rural households.

Originality/Value: The results of the study may improve the rural income distribution if they used properly.

Keyword: Fiscal policy, income inequality, co-integration.

JEL classification: P16, G23, C22.

Research type: Research paper.

\footnotetext{
${ }^{1}$ Assistant professor, Department of Economics Govt. Islamia College Civil Lines, Lahore, Pakistan khalilahmad122@gmail.com;

${ }^{2}$ Assistant professor, Department of Economics Govt. Islamia College Civil Lines, Lahore, Pakistan safibzu@gmail.com;

${ }^{3}$ Ph.D. Scholar, National College of Business Administration and Economics (NCBA\&E),

Lahore, Pakistan ayesha.haider16@yahoo.com;

${ }^{4}$ Ph.D. Scholar, National College of Business Administration and Economics (NCBA\&E),

Lahore, Pakistan. shahidncbae@gmail.com;

${ }^{5}$ Ph.D Scholar, School of Business and Economics, University of Management and

Technology. Lahore, Pakistan. economistnaushahi18@gmail.com;
} 


\section{Introduction}

In modern macroeconomic development, income distribution has gained much importance due to its vast economic and social implications. It has not only a series of concerns for the developing but also developed countries. Inequalities in income distribution continue to increase as the Gini coefficient of OECD countries was 0.29 in the mid of the 1980s that increased to 0.32 in 2011/12 (OECD, 2012). Income inequality has increased in different regions of the world in recent decades (Atkinson, 1997). The wages of low-skilled workers experienced a downward trend due to globalization that caused inequality within the economies (Tanzi and Chu, 1998). However, the incomes of high-skilled workers have increased significantly due to technological changes in the world. Moreover, the bargaining power of labor in the factor market has decreased, competition in the product market has increased due to the institutional and regulatory reforms (Tanzi et al., 1999). All the above factors, among others, may still consider as a significant cause of inequality in the world.

Although inequalities in income at some levels are considered necessary for investment and economic growth (Barro, 2000; Forbes, 2000), a higher level of inequality in income can depress macroeconomic stability and economic growth. Recent empirical studies also reveal that pace and sustainability of economic growth are impaired by a high level of income inequalities (Ostry et al., 2014). Inequalities in income can be stagnant economic growth because it worsens the health conditions of the poor and workforce (Galor and Moav, 2004), it creates economic and political instability that decreases investment (Alesina and Perotti, 1996).

The equal distribution of income is considered a necessary goal by many decisionmakers even if the primary inspirations may differ. Lower-income inequality may result in greater equal access to social, political, and economic resources. The question is which policy should be implemented by each country to surge economic growth and overcome poverty and inequality. Every government uses fiscal tools to reduce inequality and poverty. Before proceeding further, we need to understand how the fiscal policy is active in reducing inequality. We need to recognize the different methods and tools to measure inequality. There is a wide range of measures available for the measurement of inequality. A popular measure used in this study is the Gini coefficient, whose value would be zero if everyone had the same income and $100 \%$ if a single person had all the country's income.

Fiscal arrangements are considered the best tool for influence inequality through various channels. It comprises taxation (direct taxes and indirect taxes) and expenditures (development expenditures and non-development expenditures). The above fiscal appliances are uses to enhance economic growth and development. In developing countries, the transfer measures remain weak. So, the distribution of income and taxes represent an uncleared relationship. Low tax to GDP ratio, tax evasion, large informal sector, and poor administration of tax system are such factors that affect the tax side of the fiscal policy of developing countries (Alesian and Ardagna, 2009). The share of indirect taxes is more than the direct taxes in total tax 
collection in developing countries that may affect the redistribution through detrimental channels.

On the expenditure side, some studies conclude that the fiscal policy is beneficial for the redistribution of income of the lower segment of the society. The reason is that they pay fewer taxes but get more benefits from budget spending in the procedure free educational opportunities and provision of public health care facilities (Tanzi, 1989). However, some other studies explain that expenditure policy hurts the income distribution because the tax collection from the agricultural sector remains low. At the same time, the rural political elites enjoy many tax expenditures in subsidies for the agriculture sector (Gupta, 2007).

During the last four decades, income inequality remains a serious concern for the economic development of Pakistan. About 33\% population cascades below poverty. On the fiscal side, a budget deficit has remained throughout the history of Pakistan. Foreign loans and printing of money has also been a significant implication for macroeconomic performance. Later no deteriorated the situation of poverty and income inequality. An increase in indirect taxes and money supply lowers the purchasing power of the society and leads them to poverty (Arif and Farooq, 2011). Fiscal policy may directly reduce income inequality at the household level through various channels. It is also helpful for future expected income, saving, and expenditure of households through different types of fiscal arrangements. Indirect impacts of fiscal policy on household income patterns are affected through development expenditure or provision of public goods. As a surge, the development expenditures tend to lower down the income inequality.

This study investigates the influence of fiscal variables (tax and expenditure) on the redistributive characteristic of incomes and how this can affect the un-equitable. The present work varies from the earlier studies in terms of revised data set of aggregate income inequality and rural-urban inequalities. The study explores fiscal implications for income inequality using some control variables such as economic growth, financial development, and trade liberalization. The study is as follows: the next section explores the relevant literature and the research gap. Section III explains the constriction of the model, methodology, and data sources of the study. The empirical results of the econometric model discussed in section IV. The final section concludes and suggests policy implications.

\section{Literature Review}

The fundamental issue to design effective fiscal policy is addressing income inequality. The income inequality has been cumulative over time in Pakistan (Suleman, 1976), while Khandhar (1973) examines the decreasing trend of income inequality for the same period. The possible contradiction observes due to different measures of income inequality. During the 1980s, the focus was on measuring income inequality by using different indices in most studies (Mahmood and Tahir, 1984). Also, limited literature is available based on forming redistribution approaches 
(Cheema and Malik, 1985). The inequality in income remains significantly higher than the consumption inequality (Suleman, 1973). Many possible factors are determined which can influence income distribution.

A well-established mechanism of taxes and transfers can develop the distribution, and the government can manage the income distribution arrangement through resource allocation (Cubero and Hollar, 2010; Leubker, 2011). The critical role of tax nature is inevitable in making an effective policy. The impact of redistribution of income upon a country where a fair tax and transfer system exists is like the country with a higher tax rate and transfer in response to progressive income tax (Alesian and Ardagna, 1998). Engel et al. (1999) measure and examine the effect of income tax on households and their impact on income distribution.

Further, they recommend a proportional tax structure to attain a fair distribution of income rather than progressive taxation with low yield. The income distribution improves steadily over time if an economy chooses direct taxes instead of indirect taxes. The fiscal regulations are short-lived when there is an increase in the rate of tax and long-lived transfers for the reduction in public wages and employment (Alesina and Ardagna, 1998; Park, 2012).

Significant discussions exist on the success of public expenditures over tax for the fair distribution of income. The studies find out that tax-based fiscal arrangement does not improve the distribution mechanism. Bird and Zolt (2005) and Harberger (2006) examine the consequence on income distribution with public expenditures decisions and taxation systems and determine that public spending plays a vital role in correcting the distribution mechanism. Further, a progressive tax system along with augmented social spending can promote the distribution.

Many studies explore a clear trade-off between efficiency and equity in assessing the fiscal policy impact for fair income distribution (Lambert, 1990; Dollar and Aart, 2002; Mulas-Granados, 2005). The change in fiscal policy involves a factor analysis of its impact on efficiency and equity for the trade-off issue (Allan, 1993; Perugini and Martino, 2008). The empirical findings illustrate that an inverse relationship exists between income distribution and economic growth. The capitalist governments prefer growth policies (Alesina and Dani, 1984). At the same time, Deininger and Squire (1996) and Ravallion and Chen (2003) could not confirm the strong association between growth and inequality. Bayraktar and Moreno-Dodson (2015), Moreno-Dodson (2008), and Afonso et al. (2006) examine the growth impact of public spending and determine that economic growth is negatively affected by public spending that successively distresses the distribution of income.

Shirazi et al. (2001) examine the impact of fiscal policy on income distribution in Pakistan. They use microdata from the Household Integrated Economic Survey (HIES). The study also finds that rural households are deprived as compared to urban households. They suggest that fiscal policy should be pro-poor and concentrate on the low-income group in Pakistan's economy. The role of public spending in poverty 
alleviation is determined through current and development expenditures in Pakistan. The current expenditures raise income inequality and development expenditures to reduce it (Ali and Ahmed, 2010). Claus et al. (2012) explore the fiscal policy impact on income inequality among fifteen Asian countries. The results explain that public spending on health and education reduces inequality, while progressive taxation plays a significant role in income distribution.

Khan and Hashmi (2015) investigate the fiscal policy impact on income inequality. They suggest that development expenditures may be helpful to reduce inequality in Pakistan. Income inequality is not affected by financing revenue through an increase in indirect taxes. In the case of Pakistan's economy, Bhatti et al. (2015) investigate the connotation between fiscal variables and income inequality. Simulation movements are executed to find fiscal policy impact on income inequality while no budget deficit is allowed. The empirical findings show that the policy mix of government expenditures, income tax, and sales tax requires lessening income inequality. When we review the relevant literature, there are unclear results of between fiscal policy and income inequality. There is a need to investigate the country-specific analysis of the fiscal variables and rural-urban income inequality.

\section{Model Specification and Methodology}

Fiscal policy is significant to determine employment, sustainable economic growth, price stability, and income distribution for all countries. Supply-side fiscal policy has a significant impact on society's income; it also influences the revenue collection for the budget requirement. The relationship between income distribution and taxes is a complex phenomenon because of weak transfer measures. Many factors can affect the supply-side performance of the transition nation fiscal policy, such as low tax to GDP, large informal sectors, tax evasion, and poor tax administration (Alesian and Ardagna, 2009). The more share of the indirect taxes than direct tax policy is dominant; this policy may cause the redistribution through detrimental channels in developing worlds. On the expenditure side, one view supports that the benefit of income redistribution in developing nations. The poor segment of the society pays less income tax and gain more benefits through disbursement budget spending on free health and education opportunity (Tanzi, 1989). The other view supports that the expenditure policy hurts the distribution of income because, on the one hand, low tax collection from the agriculture sector, many subsidies' expenditures for agriculture development, non-development expenditure by the political elite (Gupta, 2007).

Large numbers of indexes, methods, and formulas measure the income inequality in literature, but the Gini coefficient is considered a more critical measurement. Lorenz Curve is used to drive the Gini coefficient; if the value of this coefficient approaches one its means that perfect equality exits between percentage change in income and population. This study also used the Gini coefficient for total, urban-ruler income inequality, and fiscal variable in the shed light of some most relevant macroeconomics explanatory variables suggested by (Alesian and Ardagna (2009); Galbraith (2007). 
For an open economy, trade liberalization has a positive impact on income distribution through various channels. On the one hand, trade liberalization may improve the competition in both the labor and capital market, while on the other hand, it may improve the welfare of the society (Wade, 2004). Another significant variable is financial development which is a more important factor among others. Financial development has a negative relationship with income inequality at the early stages of financial development, but it positively relates to inequality at a higher stage of financial development (Tan and Law, 2012). Nikoloski (2012) concludes that financial sector development has a positive relationship with income at an early stage, while on the later stage of financial development, a negative and robust impact on income distribution.

Growth of the overall macroeconomic development is considered a key variable to determine income inequality. The seminal work on the relationship between growth and inequality by Kuznets (1955) investigates that inequality first increases and later decreases with development. Robinson (1976) develops a model to investigate the agriculture (rural) and industrial (urban) sectors. He fined a solid and robust result in the urban bur, not in rural areas. Later, Barro (2000) investigates the empirical link on a more extensive data set and concludes that there is no robust relationship between income and inequality. Based on the above discussion and literature review, we developed a model for income and inequality with fiscal and financial variables for total, urban, and rural inequality. When we talk about the econometric model, it helps to compact the complex phenomena, but it also helps the researcher investigate the cause and effect for current behavior and future projections. Large numbers of social, cultural, and economic indicators, directly and indirectly, impact income inequality, but this study only focuses on selected macroeconomic variables.

$$
\mathrm{TING}=(\mathrm{FD}, \mathrm{GE}, \mathrm{PCg}, \mathrm{TAX}, \mathrm{INF}, \mathrm{TR})
$$

Where, TINQ= total income inequality measured with Gini coefficient over time, $\mathrm{FD}=$ is proxy of financial development measured as a credit to the private sector as a share of GDP, GE= indicate the demand side of fiscal policy used as total government expenditures as a share of GDP, $\mathrm{PCg}=$ per capita growth rate, Tax= supply side of fiscal policy as total tax revenue as a share of GDP, INF= Inflation is measure as GDP deflator, $\mathrm{TR}=$ as an export plus imports divided by GDP, The econometrics model can be written as the following in equation two below.

$$
\mathrm{TINQ}_{\mathrm{t}}=\alpha_{0}+\alpha_{1} \mathrm{FD}_{\mathrm{t}}+\alpha_{2} \mathrm{GE}_{\mathrm{t}}+\alpha_{3} \mathrm{PCg}_{\mathrm{t}}+\alpha_{4} \mathrm{TAX}_{\mathrm{t}}+\alpha_{5} \mathrm{TR}_{\mathrm{t}}+\mu t
$$

Where TINQt total inequality, while $\mu t$ is an error term and $\mathrm{t}$ stand for time. The main contribution of this study is to investigate how fiscal policy and other macroeconomic variables impact urban inequality. For urban inequality, equation-3 as follows:

$$
\mathrm{UINQ} t=\beta_{0}+\beta_{1} \mathrm{FD} t+\beta_{2} \mathrm{GE} L t+\beta_{3} \mathrm{PCg} t+\beta_{4} \mathrm{TAX} t+\beta_{5} \mathrm{TR} t+\mathrm{e} t
$$


Where UINQt stands for the urban inequality with the same independent variable discuss above equations 2 and 3. For this model error term, it is used for estimations. The growth of the nation's income and fiscal reforms have what type of impact on rural inequality. This relationship has more importance in the case of Pakistan because there are large numbers of rural-urban inequalities, as discuss by Robinson (1976). The estimated equation of RINQ $t$ and independent variables in equation-4 as below

$$
\mathrm{RINQ}_{\mathrm{t}}=\gamma_{0}+\gamma_{1} \mathrm{FD} t+\gamma_{2} \mathrm{GE} t+\gamma_{3} \mathrm{PCg} t+\gamma_{4} \mathrm{TAX} t+\gamma_{5} \mathrm{TR} t+\mathrm{V} t
$$

RINQt equals rural income inequality; in the model, $\mathrm{V} t$ is an error term and $\mathrm{t}$ for time series analysis with the same set of explained variables.

Time series data of total inequality growth and bifurcated with rural-urban areas of Pakistan are dependent variables in three different models. Apart from this core variable, financial development, government expenditure, per capita growth, tax revenue, inflation rate, and trade liberalization are also taken as independent variables. All these variables are taken from the World Development Indicators online database and Pakistan Bureau of Statistics from 1985 to 2018. Income inequality data is taken from Jamal (2016) for both rural and urban income inequality. We use the moving average method is used for remains two years value.

The paper's methodology is based on quantities measures such as stationary of the data, co-integration of econometrics model, and later short-run dynamics. Large numbers of models and tests are available for co-integration, but this study chooses the Autoregressive Distributed Lag Model (ARDL) developed by Pesaran et al. (2001) and later Narayan (2005) augmented the bounds values. This method is more potent against short-run dynamics without losing extended run information. It produces more relevant, unbiased, and efficient results for a small sample size. Second, this approach is more appropriate for mix integrated order of stationarity order $\mathrm{I}(0)$ or $\mathrm{I}(1)$. The two-step calculation procedure has been followed to measure the co-integration. In the first step, we calculate F-statistic's bounds for the conformation of long-run association among fiscal policy and income distribution. Second, it can calculate the short-run and long-run coefficients with the help of the re-parameterization process without losing important information.

The above-specified model has been estimated for finding the coefficients of longrun and associated ECM. ARDL (p, q1, q2) for fiscal implications of aggregate and rural-urban income inequality in the shed light of some macroeconomics variables because this is the generalized form of these models which have the following form:

$\Delta y_{t}=\alpha_{0}+\sum_{i=1}^{p} \alpha_{1 W t-i}+\sum_{i=1}^{q_{1}} \alpha_{2} \Delta x_{t-i}+\sum_{i=1}^{q_{2}} \alpha_{3} \Delta \operatorname{cont}_{t-i}+\varepsilon_{t} 6$

Where, y represents income inequality along with rural-urban income status, $\mathrm{w}$ and $\mathrm{x}$ denote supply side and demand side fiscal policy variables in different models with 
other control variables. This specified equation is the generalized form of different models used in the study.

Selection of the order of ARDL ( $p, q 1, q 2)$ has been made based on Schwartz Bayesian Criterion (SBC). The short-run dynamics parameters are presented in the next step which have been obtained by estimating error correction model associated with long-run estimates. The generalized form of the ECM model has been specified as follows:

$$
\Delta Y_{t}=\alpha_{0}+\sum_{i=1}^{p} \alpha_{i} \Delta w_{t-i}+\sum_{j=1}^{q} \alpha_{j} \Delta x_{t-j}+\sum_{k=1}^{q} \alpha_{k} \Delta \text { CONTROL }_{t-k}+\varepsilon E T_{t-1}+\mu_{t}
$$

Where $\alpha \mathrm{i}, \alpha \mathrm{j}, \alpha \mathrm{k}$ and $\alpha \mathrm{o}$ are short-run coefficients while $\varepsilon$ is speed of adjustment of the model's convergence to the long run equilibrium.

\section{Empirical Results}

Inequality in the distribution of income has also gained much importance in the development process. It hurts the growth outcomes and worsens the poverty level in the economy. The study empirically investigates how the fiscal composition can affect the total and the urban and rural inequality of the economy of Pakistan. The descriptive statistics are shown in Table-1. Before employing the regression, it seems logical to check the nature of the data. It means to confirm that the data set is usually distributed, and no outlier exists in the series. The measures of central tendency, normality, and data dispersion look good enough to carry on the regression analysis.

Table 1. Descriptive statistics

\begin{tabular}{lccccccccc}
\hline & TINQ & UINQ & RINQ & FD & GE & PCG & TAX & INF & TR \\
\hline Mean & 0.4025 & 0.4186 & 0.3617 & 23.094 & 21.79 & 1.997 & 12.25 & 104.2 & 30.31 \\
\hline Median & 0.4073 & 0.4200 & 0.3657 & 24.157 & 21.52 & 2.092 & 12.960 & 69.741 & 29.99 \\
\hline Maximum & 0.4198 & 0.4210 & 0.3763 & 29.786 & 26.70 & 5.222 & 14.480 & 269.70 & 37.81 \\
\hline Minimum & 0.3536 & 0.397 & 0.3190 & 15.386 & 16.94 & -1.843 & 9.120 & 15.18 & 24.12 \\
\hline Std. Dev. & 0.0160 & 0.002 & 0.0136 & 4.213 & 3.214 & 1.806 & 1.744 & 88.35 & 3.299 \\
\hline Skewness & -1.2789 & -1.243 & -1.329 & -0.3843 & 0.089 & -0.158 & -0.466 & 0.727 & 0.088 \\
\hline Kurtosis & 4.1636 & 4.050 & 4.318 & 2.084 & 1.710 & 2.291 & 1.661 & 1.990 & 2.648 \\
\hline Jarque-Bera & 11.515 & 10.668 & 12.851 & 2.083 & 2.472 & 0.877 & 3.811 & 4.574 & 0.225 \\
\hline Probability & 0.051 & 0.042 & 0.032 & 0.352 & 0.290 & 0.644 & 0.1435 & 0.301 & 0.893 \\
\hline Sum & 14.088 & 14.65 & 12.66 & 808.2 & 762.9 & 69.91 & 429.0 & 3647.8 & 1061.1 \\
\hline Sum Sq. & 0.0871 & 0.072 & 0.0636 & 603.6 & 351.3 & 110.9 & 103.4 & 4. & 370.1 \\
Dev. & & & & & & & & & \\
\hline Observation & 35 & 35 & 35 & 35 & 35 & 35 & 35 & 35 & 35 \\
s & & & & & & &
\end{tabular}

Source: Own creation.

For estimation, first, it is checked that either data is stationary (mean zero and variance remains constant, and covariance remains zero over time) or non-stationary. Most of the series are stationary at a level such as GDP growth and sub-sectors of 
GDP and trade liberalization, but population growth and financial development are stationary at first difference. The results are reported in table-3 below. For ARDL cointegration regression analysis, the data set must be stationary at the level or first difference. Our data pass all quality checks, such as there is no autocorrelation between variables, all series are typically distributed, and finally, the bottom-line estimated series have no problem of a unit root.

Table 2. Stationarity Test

\begin{tabular}{lcccc}
\hline Variables & T-statistic I $(0)$ & Lages & T-statistic I $(1)$ & Lages \\
\hline TINQ & $-3.238^{* *}$ & 0 & $-6.101^{*}$ & 1 \\
\hline UINQ & $-4.136^{*}$ & 0 & $-6.456^{*}$ & 1 \\
\hline RINQ & $-2.132 * * *$ & 0 & $-5.681^{* *}$ & 1 \\
\hline FD & -1.354 & 0 & $-4.611^{* *}$ & 1 \\
\hline GE & -1.406 & 0 & $-6.181^{*}$ & 1 \\
\hline PCg & $-3.366^{* *}$ & 0 & $-7.046^{*}$ & 2 \\
\hline TAX & -1.366 & 0 & $-5.871^{* *}$ & 1 \\
\hline INF & 3.557 & 0 & $-4.643^{* *}$ & 1 \\
\hline TR & $-2.344 * * *$ & 0 & $-7.470 *$ & 1
\end{tabular}

Note: $*, * * * * *$, indicates the $99 \%, 95 \%, 90 \%$ level of signifiance

Source: Own creation.

To measure the ARDL co-integration, a two-step calculation procedure has been adopted. In the first step, we have calculated the bounds F-statistics results in table3. It is observed that Calculated F-statistics are more significant than the value of the upper bound in the models. It is confirmed that the long-run association exists between inequality and independents variables. It shows that some linear combinations exit in the variables. Now, we move to the next step to calculate the linear coefficients of the short-run and long-run.

Table- 4 shows the long-run results. Three models have been estimated where the total inequality, urban inequality, and rural inequality have been taken as dependent variables, respectively. The model-1 shows that financial development and inflation positively and significantly impact total inequality in Pakistan. However, the impact of tax on inequality is positive but insignificant. It is evident from the results that the fruits of financial development are enjoyed mainly by society's urban and rural elites. Thus, it worsens the inequality in Pakistan.

Table 3. Results of Bounds Test for Co-integration

\begin{tabular}{lllll}
\hline Equation & F-Statistics & $\begin{array}{l}\text { Critical } \\
\text { Value } \\
\text { Lower } \\
\text { Bound }\end{array}$ & $\begin{array}{l}\text { Critical } \\
\text { Value } \\
\text { Upper } \\
\text { Bound }\end{array}$ & Conclusion \\
\hline TINQ=FD,GE,PCg,Tax,INF,TR & & 2.8956 & 4.3310 & Co-integration \\
& $\begin{array}{l}88.39 \\
(95 \%)\end{array}$ & & & \\
\hline UINQ=FD,GE,PCg,Tax,INF,TR & $\begin{array}{l}96.37 \\
(95 \%)\end{array}$ & 2.8956 & 4.3310 & Co-integration \\
& $\begin{array}{l}15.13 \\
(95 \%)\end{array}$ & 2.8956 & 4.3310 & Co-integration \\
\hline RINQ=FD,GE,PCg,Tax,INF,TR & & & & \\
\hline
\end{tabular}

Source: Own creation. 
Similarly, inflation directly impacts the purchasing power of households, so it also causes inequality to rise. As for as the taxes are concerned, these are levied on a small proportion of the population. Besides, tax evasion is a significant problem in developing economies, including Pakistan. Thus, the impact of taxes on inequality is insignificant. Government expenditure, per capita growth, and trade, have a negative but significant impact on total inequality in Pakistan. The justification for these results is that due to government expenditure, employment opportunities increase, and household income increases. Similarly, with an increase in per capita growth, the inequality reduces through an increase in per capita incomes.

Table 4. Long run Estimates of Fiscal policy and Inequality

\begin{tabular}{lccc}
\hline Variables & $\begin{array}{c}\text { Model-1 TINQ } \\
(1,1,0,0,0,1,0)\end{array}$ & $\begin{array}{c}\text { Model-2 UINQ } \\
(1,1,0,0,0,1,0)\end{array}$ & $\begin{array}{c}\text { Model-3 RINQ } \\
(1,0,0,1,0,0,0)\end{array}$ \\
\hline FD & 0.3986 & 0.1691 & 0.1360 \\
& {$[.013]^{* *}$} & {$[.016]^{* *}$} & {$[.717]$} \\
\hline GE & -0.8117 & -0.3645 & -0.9755 \\
& {$[.000]^{*}$} & {$[.000]^{*}$} & {$[.011]^{* *}$} \\
\hline PCg & -0.3658 & -0.1778 & -0.2994 \\
& {$[.046]^{* *}$} & {$[.036]^{* *}$} & {$[.608]^{* * *}$} \\
\hline TAX & 0.1835 & 0.9531 & 0.9316 \\
& {$[.565]$} & {$[.498]$} & {$[.056]^{* * *}$} \\
\hline INF & 0.7004 & 0.3176 & 0.7786 \\
& {$[.000]^{*}$} & {$[.000]^{*}$} & {$[.001]^{* *}$} \\
\hline TR & -0.2856 & -0.1114 & 0.5218 \\
& {$[.048]^{* *}$} & {$[.076]^{* * *}$} & {$[.071]^{* * *}$} \\
\hline Constant & 0.41701 & 0.4247 & 0.3504 \\
& {$[.000]^{*}$} & {$[.000]^{*}$} & {$[.000]^{*}$} \\
\hline
\end{tabular}

Source: Own creation.

Furthermore, when trade volume increases, people try to involve themselves in trade and business-related activities, which causes an increase in their incomes, and this ultimately results in inequality reduction. Similar results have been found in model2 with the dependent variable of urban inequality. However, there is a slight difference in the results of model 3. This model shows that financial development has a positive but insignificant impact on rural inequality in Pakistan. Taxes and trade have a positive and significant impact on rural inequality. In rural areas, financial development worsens inequality, but the effect is insignificant due to the limited access of rural poor to the financial benefits. Taxes and trade directly hurt the poor and cause rural inequality to rise because the rural elite owns the trade-related business and can avoid the tax burden. Thus, the limited access of the rural poor to financial resources and other economic activities causes inequality. Government expenditures have a negative and significant impact on rural inequality in Pakistan. The results are given in table 4 below.

Table 5 represents the short-run outcomes obtained from the ECM version of the ARDL model. The ECM coefficient shows the speed of adjustment for the short-run to restore the long-run equilibrium in the models. It should have a statistically significant coefficient with a negative sign. The results show that financial 
development, taxes, and inflation have a constructive and significant impact on total, urban-rural inequality in the short run. It means that all the variables mentioned above cause to increase the inequality in Pakistan. However, government expenditure, per capita growth and trade have an adverse and significant impact on total and urban inequality in the short run but constructive and insignificant impact on rural inequality in the short run in Pakistan.

Table 5. Short run Estimates of Fiscal policy and Income Inequality

\begin{tabular}{lccc}
\hline Variables & $\begin{array}{c}\text { Model-1 } \Delta \text { TINQ } \\
(1,1,0,0,0,1,0)\end{array}$ & $\begin{array}{c}\text { Model-2 } \Delta \text { UINQ } \\
(1,1,0,0,0,1,0)\end{array}$ & $\begin{array}{c}\text { Model-3 } \Delta \text { RINQ } \\
(1,0,0,1,0,0,0)\end{array}$ \\
\hline$\Delta$ FD & 0.2265 & 0.1008 & 0.3772 \\
& {$[.000]^{*}$} & {$[.000]^{*}$} & {$[.714]$} \\
\hline$\Delta \mathbf{G E}$ & $0-.1906$ & -0.8423 & -0.2705 \\
& {$[.000]^{*}$} & {$[.000]^{*}$} & {$[.029]^{* *}$} \\
\hline$\Delta \mathbf{P C g}$ & -0.8590 & -0.4108 & 0.3092 \\
& {$[.058]^{* * *}$} & {$[.039]^{* *}$} & {$[.028]^{* *}$} \\
\hline$\Delta \mathbf{T A X}$ & 0.4310 & 0.2203 & 0.2583 \\
& {$[.567]$} & {$[.501]$} & {$[.032]^{* *}$} \\
\hline$\Delta \mathbf{I N F}$ & 0.6727 & 0.3046 & 0.2159 \\
& {$[.002]^{*}$} & {$[.002]^{*}$} & {$[.004]^{*}$} \\
\hline$\Delta \mathbf{T R}$ & -0.6708 & -0.2573 & 0.1447 \\
& {$[.040]^{* *}$} & {$[.067]^{* * *}$} & {$[.013]^{* *}$} \\
\hline $\mathbf{E C M}$ & -0.2348 & -0.2310 & -0.2772 \\
& {$[.000]^{*}$} & {$[.000]^{*}$} & {$[.000]^{*}$} \\
\hline $\mathbf{R}^{2} / \mathbf{D W}$ & $0.98 / 1.89$ & $0.97 / 1.82$ & $0.95 / 1.72$ \\
\hline
\end{tabular}

Source: Own creation.

Table 6. Summary Statistics of Diagnostic Tests

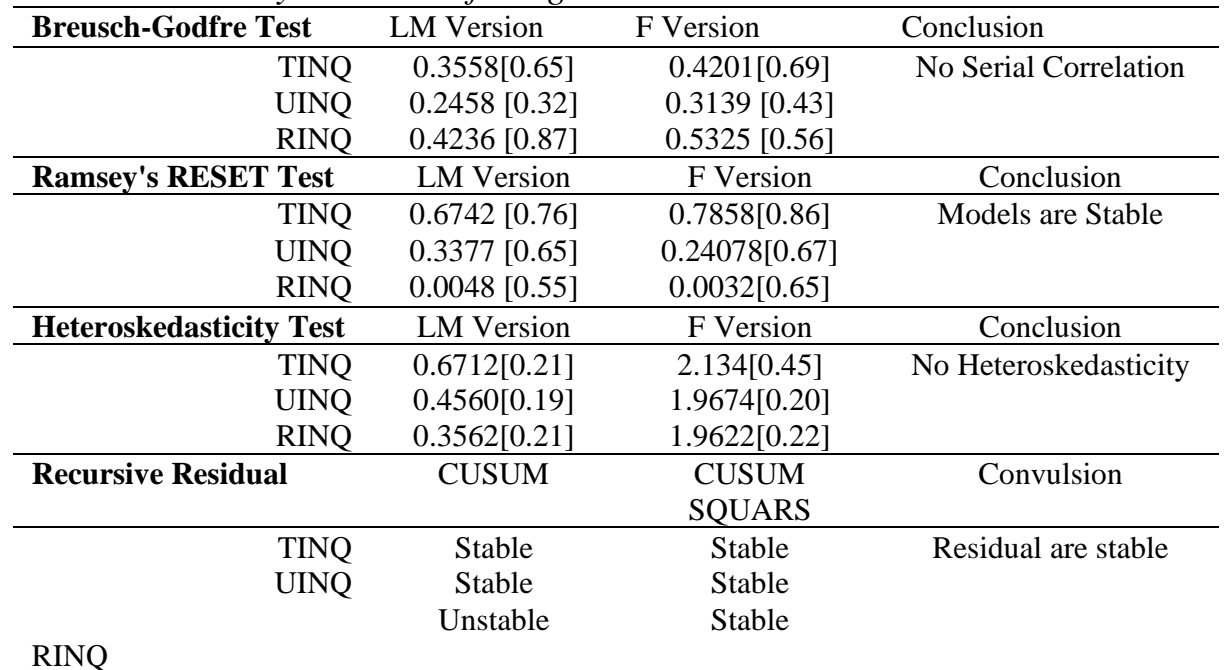

Source: Own creation.

Table 6 shows the summary statistics of all relevant diagnostic tests of the above three models. The above-calculated F-statistics and LM version of test statistics show the absence of serial correlation and heteroscedasticity in an empirical analysis of all 
three models. There is no existence of autocorrelation in recursive residuals. Furthermore, the reset test also confirms the excellent fit of the models and reliability of empirical analysis for short and long-run coefficients.

\section{Conclusions and Policy Suggestions}

In this study, we have tried to investigate the impact of fiscal policy on the total urbanrural inequality in Pakistan. For this purpose, we have applied time-series data and autoregressive distributed lag models for both long-run and short-run co-integration. Three models have been estimated where the total inequality, urban inequality, and rural inequality have been taken as dependent variables, respectively. Model 1 depicts that financial development and inflation have a significant positive impact on total inequality in Pakistan.

However, the impact of tax on inequality is positive but insignificant. Government expenditures, per capita growth, and trade liberalization, have a negative and significant impact on total inequality in Pakistan. Similar results have been found in model 2 with the dependent variable of urban inequality. However, there is a slight difference in the results of model 3. The outcomes show that financial development has a positive but insignificant impact on rural inequality in Pakistan.

It is evident from the results that the fruits of financial development are enjoyed mainly by society's urban and rural elites. Thus, it worsens the inequality in Pakistan. As for as the taxes are concerned, these are levied on a small proportion of the population. Besides, tax evasion is a significant problem for the developing economies, including Pakistan. Thus, the impact of taxes on inequality is insignificant. Government expenditure, per capita growth and trade, have a negative but significant impact on total, urban, and rural inequality in Pakistan.

The justification for these results is that employment opportunity increases and the income of the households also increases due to government expenditures. Whether the inequality increases or decreases depends upon how the government revenues are spent. The inequality situation gets better if the government invests in social goods like health, education, and infrastructure in improving the quality of life of the households. Thus, the nature of spending public money and who gains the benefits from this spending decides the nature of inequality in the country. The inequality may be addressed in a better way if the poor get much fruit from public spending. So, the fiscal policy may be considered as an essential component of reducing inequality. While on the tax side government should ease the tax burden for rural households through tax reforms.

Similarly, with an increase in per capita growth, the inequality reduces through an increase in per capita incomes. Furthermore, when trade volume increases, people involve themselves in trade and business-related activities. That causes an increase in their incomes, and this ultimately results in inequality reduction. 


\section{References:}

Afonso, A., Christiane, N., Philipp, R. 2006. Fiscal consolidations in the Central and Eastern European countries. Review of World Economics, 142(2), 402-421.

Alesina, A., Dani R. 1984. Distributive Politics and Economic Growth. Quarterly Journal of Economics. 109(2) 465-490.

Alesina, A., Ardagna, S. 1998. Tales of fiscal adjustment. Economic Policy, 13(27), 488 545.

Alesina, A., Perotti, R. 1996. Income distribution, political instability, and investment. European Economic Review, 40(6), 1203-1228.

Ali, S., Ahmad, N. 2010. The Effects of Fiscal Policy on Economic Growth: Empirical Evidence based on the Time Series data from Pakistan. The Pakistan Development Review, 49(4), 497-512.

Atkinson, A.B. 1997. Bringing income distribution in from the cold. The Economic Journal, 107(441), 297-321.

Barro, R.J. 2000. Inequality and Growth in a Panel of Countries. Journal of Economic Growth, 5(1), 5-32.

Bayraktar, N., Moreno-Dodson, B. 2015. How can public spending help you grow? An empirical analysis for developing countries. Bulletin of Economic Research, 67(1), 30-64.

Bhatti, A.A., Batool, Z., Naqvi, H.A. 201. Fiscal policy and its role in reducing income inequality: a CGE analysis for Pakistan. The Pakistan Development Review, 843-862.

Bird, R.M., Zolt, E.M. 2005. The limited role of the personal income tax in developing countries. Journal of Asian Economics, 16(6), 928-946.

Cheema, A.A., Malik, M.H. 1985. Changes in Consumption Patterns and Employment under Alternative Income Distribution in Pakistan. The Pakistan Development Review, 24(1), 1-22.

Deininger, K., Squire, L. 1999. A New Data Set Measuring Income Inequality. World Bank Economic Review 10(3), 565-591.

Dollar, D., Aart, K. 2002. Growth is Good for the Poor. Journal of Economic Growth, 7(3), 195-225.

Engel, E., Galetovic, A., Raddatz, C. 1999. Taxes and Income Distribution in Chile: Some Unpleasant Redistributive Arithmetic. Journal of Development Economics, 59(1), 155-192.

Forbes, K.J. 2000. A Reassessment of the Relationship Between Inequality and Growth. American Economic Review, 90(4), 869-887.

Galbraith, J.K. 2007. Global inequality and global macroeconomics. Journal of Policy modeling, 29(4), 587-607.

Galor, O., Moav, O. 2004. From Physical to Human Capital Accumulation: Inequality and the Process of Development. Review of Economic Studies, 71(4), 10011026.

Gupta, A.S. 2007. Determinants of Tax Revenue Efforts in Developing Countries. International Monetary Fund, Working Paper No. 07/184.

Harberger, A.C. 2006. Taxation and income distribution: Myths and realities. The challenges of tax reform in a global economy, 13-37.

Jamal, H. 2016. Smoothing Sporadic Poverty and Inequality Estimates: Pakistan, 19852016. MPRA paper no. 91834.

Khan, R.E.A., Hashmi, B.J. 2015. Fiscal Policy and Income Inequality in Pakistan: An ARDL Approach. European Journal of Economic Studies, 3, 161-174. 
Khandkar, R. 197. Distribution of Income and Wealth in Pakistan. The Pakistan Development Review, 13(2\&3), 41-53.

Kuznets, S. 1955. Economic Growth and Income Inequality. American Economic Review, 45(1), 1-28.

Lambert, P.J. 1990. The equity-efficiency trade-off: Breit reconsidered. Oxford Economic Papers, 42(1), 91-104.

Mahmood, Z., Tahir, S. 1984. Income inequality in Pakistan: an analysis of existing evidence. The Pakistan Development Review, 23(2/3), 365-379.

Moreno-Dodson, B. 2008. Assessing the impact of public spending on growth-an empirical analysis for seven fast growing countries. The World Bank.

Mulas-Granados, C. 2005. Fiscal adjustments and the short-term trade-off between economic growth and equality. Revista de Economia Pública, 172(1), 61-92.

Nikoloski, Z. 2012. Financial sector development and inequality: Is there a financial Kuznets curve? Journal of international development, 25(7), 897-911.

OECD. 2012. Income Inequality and Growth: The Role of Taxes and Transfers. OECD Economics Departments Policy Notes, No. 9, January.

Ostry, M.J.D., Berg, A., Tsangarides., C.G. 2014. Redistribution, inequality, and growth. IMF Staff discussion note, International Monetary Fund, Washington, D.C.

Park, C.Y. 2012. Taxes, Social Transfers, and Inequality in Asia. Presentation at the IMFJapan High-Level Tax Conference: Emerging Tax Issues in Asian Countries. Tokyo, 31 January-3 February.

Perugini, C., Martino, G. 2008. Income Inequality within European Regions: Determinants and Effects on Growth. Review of Income and Wealth, 54(3), 373-406.

Ravallion, M., Chen, S. 2003. Measuring pro-poor growth. Economics Letters, 78(1), 93-99.

Robinson, S. 1976. A Note on the U-hypothesis Relating Income Inequality and Economic Development. American Economic Review, 66(3), 473-440.

Shirazi, N.S., Ilyas, M., Ahmed, M. 2001. Redistributive Effect of Fiscal Policy Across the Income Groups in the Urban Rural Areas of Pakistan. The Pakistan Development Review, 40(4), 519-533.

Suleman, R.M.U. 1976. Employment, Income Distribution and Social Justice. Pakistan Economic and Social Review, 14(1/4), 101-118.

Tan, H.B., Law, S.H. 2012. Nonlinear dynamics of the finance-inequality nexus in developing countries. Journal of economic inequality, 10(4), 551-563.

Tanzi, V., Chu, K.Y. (Eds.). 1998. Income distribution and high-quality growth. MIT Press.

Tanzi, V. 1989. The Impact of Macroeconomic Policies on the Level of Taxation and the Fiscal Balance in Developing Countries. Staff Papers International Monetary Fund, 36(3), 633-656.

Tanzi, V., Chu, K.Y., Gupta, S. (eds.). 1999. Economic Policy and Equity. Washington: International Monetary Fund.

Wade, R.H. 2004. Is Globalization Reducing Poverty and Inequality? World Development, 32(4), 567-589. 